DOI 10.22363/2313-2329-2021-29-1-88-98

UDC 338

Research article / Научная статья

\title{
Innovation and productivity: the case of Nordic countries
}

\author{
Svetlana A. Balashova ${ }^{\varpi}$, Anastasia A. Abramova \\ Peoples' Friendship University of Russia (RUDN University), \\ 6 Miklukho-Maklaya St, Moscow, 117198, Russian Federation \\ $\varangle$ balashova-sa@rudn.ru
}

\begin{abstract}
Denmark, Finland, Iceland, Norway, and Sweden form a group of the Nordic countries, considered welfare states and the global leaders in innovative development. The link between the growth rate of total factor productivity and innovative development, controlling such factors as trade openness and prices volatility in commodity markets, is examined. The econometric analysis results show that the relationship between the level of innovative development and the rate of productivity growth is more robust for the Nordic countries than for the EU countries on average. Features of the national innovation systems and financing of R\&D in the Nordic countries and factors contributing to the impact of innovation activity on productivity are highlighted.

Keywords: total factor productivity, R\&D expenditures, Nordic countries, innovative development, innovative activity, national innovation system

Article history: received 10 October 2020; revised 14 November 2020; accepted 5 December 2020.

For citation: Balashova, S.A., \& Abramova, A.A. (2021). Innovation and productivity: The case of Nordic countries. RUDN Journal of Economics, 29(1), 88-98. http://dx.doi.org/ $10.22363 / 2313-2329-2021-29-1-88-98$
\end{abstract}

\section{Инновации и производительность: особенности скандинавских стран}

\author{
С.А. Балашова ${ }^{\square}$, А.А. Абрамова \\ Российский университет дружбь народов, \\ Российская Федерация, 117198, Москва, ул. Миклухо-Маклая, д. 6 \\ balashova-sa@rudn.ru
}

Аннотация. Предложена модель, позволяющая объяснить динамику совокупной факторной производительности в странах ЕС такими факторами, как участие в международной торговле, темп роста расходов на НИОКР и неопределенность мировых цен на нефть. Результаты оценки модели показали, что для стран Северной Европы, которые являются глобальными лидерами инновационного развития на протяжении послед-

(C) Balashova S.A., Abramova A.A., 2021

(c) () This work is licensed under a Creative Commons Attribution 4.0 International License https://creativecommons.org/licenses/by/4.0/ 
них восьми лет, взаимосвязь между уровнем инновационного развития и темпом роста производительности более высокая, чем для стран ЕС в среднем. Выделены особенности организации национальной инновационной системы и финансирования НИОКР скандинавских стран, а также факторы, способствующие вкладу инновационной активности в производительность.

Ключевые слова: совокупная факторная производительность, затраты на НИОКР, скандинавские страны, инновационная активность, инновационное развитие, национальная инновационная система

История статьи: поступила в редакцию 10 октября 2020 г.; проверена 14 ноября 2020 г.; принята к публикации 5 декабря 2020 г.

Для цитирования: Balashova S.A., Abramova A.A. Innovation and productivity: the case of Nordic countries // Вестник Российского университета дружбы народов. Серия: Экономика. 2021. Т. 29. № 1. С. 88-98. http://dx.doi.org/10.22363/2313-2329-2021-29-1-88-98

\section{Introduction}

Innovation and innovative development are among the main topics of the past two decades of the $21^{\text {st }}$ century. In the European Union, back in 2000, the Lisbon Strategy was adopted, which set itself to build an innovative economy. The Europe 2020 development program adopted in 2010 set no less ambitious goals - achieving world leadership in the field of innovation under the slogan "European Union - Innovation Union". In line with the general concept, each EU country and other European countries have adopted national strategies for innovative development (Matyushok, 2011; Matyushok, Kravtsov, 2011). We can say that the efforts led to complete success; all countries have achieved the goals and implemented the innovative strategies fully. However, many European countries are consistently in the top 20 world leaders in innovative development ranked by the Global Innovation Index (GII).

The Nordic countries are highly successful among European countries in terms of innovation indicators: Sweden, Denmark and Finland are among the top 10 world leaders, while Norway and Iceland are ranked 20 and 21 respectively among 130 countries of the world according to the Global Innovation Index 2020.

One of the main indicators of achieving the goals of innovative development is the share of $R \& D$ expenditures in the gross domestic product. Increasing expenditures on R\&D should ensure the leadership in the technology race, enlarging the output of high-tech products, and, as a result, the quality of life should be improving. In the long term, R\&D expenditures should support economic growth by increasing productivity of labour and capital.

Despite huge R\&D expenditures globally, and primarily in developed countries, total factor productivity has been increasing at a slow pace over the past 20 years. After the crisis of 2008-2009, a global trend towards a slowdown in economic growth was formed. Against this slowdown's backdrop, the growth in R\&D spending may seem redundant, with no productivity gain, at least in the short term.

The study aims to analyze the relationship between the growth rates of total factor productivity (TFP) and the growth rates of R\&D expenditures controlling other factors. We compare the aggregated data of EU countries with the case of the Nordic countries, which are leaders in innovative development by many criteria. In the last section, we identify factors contributing to a higher impact of R\&D on TFP growth for these countries. 


\section{Theoretical background of the study and a brief review of the literature}

In a broad sense, productivity is understood as the ratio of the output (measured in one way or another) to the resources expended. Productivity can show technological change, resource efficiency, real cost savings, etc.

There are several methods for measuring output. Productivity is measured in relation to one resource (the ratio of output to labour expended - labour productivity - is an example of such an approach) or in relation to a group of factors (multifactor or total factor productivity of TFP) (OECD, 2001).

The multi-factor type of productivity is labour and capital productivity. In general terms, the formula for measuring labour and capital productivity (or total factor productivity, TFP) can be written as follows:

\section{Labour and capital productivity =}

(Quantitative index of gross value added) / (Quantitative index of labour and capital used in the process of GVA production).

This measure reflects technological changes in general, economies of scale, changes in the efficiency of primary resources, etc. "When the capital input measure is an aggregator of detailed types of assets... and ....reflect quality change, the effects of embodied technical change are picked up by the capital input term, and only disembodied technical change affects" TFP (OECD, 2001).

There parametric and non-parametric approaches to productivity measures. The growth accounting approach is a prominent example for non-parametric techniques.

In neoclassical growth models (Solow, 1956), output is determined by the generalized Cobb - Douglas production function

$$
Y_{t}=\operatorname{TFP}_{t} K_{t}^{1-\beta} L_{t}^{\beta},
$$

where $Y_{t}$ is output, $\operatorname{TFP}_{t}$ is total factor productivity, $K$ is physical capital, and $L$ is labour utilized in the production process.

$L$ is the effective amount of labour (that is, the quantity and quality of workers), and $K$ accumulates all types of physical capital. In this form, the production function is used by the World Bank experts for predicting the economic growth rates of the countries of the world (see, for example, (Sinha, 2017)), as well as by the experts of the International Monetary Fund (see, for example, (Cubeddu et al., 2014)).

In the approach developed by Daniel Jorgenson and his followers, capital invested in information technology is distinguished as a special type of capital. As shown in numerous studies (e. g. (Jorgenson, Vu, 2016)), ICT capital contributes significantly to economic growth. At the same time, the amortization of ICT capital occurs much faster than other capital assets.

Applying the decomposition of labour and capital equation (1), turning to the growth rates (measured as differences in natural logarithms) and taking GDP as a measure of output, we have

$$
\begin{gathered}
\Delta \ln (\mathrm{GDP})=\Delta \ln \mathrm{T} \mathrm{FP}+v^{\mathrm{ICT}} \Delta \ln K^{\mathrm{ICT}}+ \\
+v^{N \mathrm{ICT}} \Delta \ln K^{N \mathrm{ICT}}+v^{H} \Delta \ln (H)+v^{L Q} \Delta \ln (L Q) .
\end{gathered}
$$


Here $v^{\text {ICT }}$ is the share of consumed ICT capital in the output, $v^{N \text { ICT }}$ is the share of consumed non-ICT capital in the output, $v^{H}$ is the share of the amount of labour in the output, and $v^{L Q}$ is the share of the quality of labour in the output.

If the hypothesis of constant returns to the scale of production is true, the sum of these shares is equal to one.

From equation (2), we can find the growth rate of the total factor productivity $\Delta \ln T F P$ as the difference between the GDP growth rate and the contribution of labour and capital growth rates. With this definition, total factor productivity is not measured directly. Still, it results from measuring GDP, employment, capital consumed, and, of course, depends on the economic growth model that links all these values.

Within this article's framework, we will not consider other approaches to determining TFP (see, for example, a brief overview of methods for determining TFP in (Maslennikov, 2015)). However, the empirical results do not support the hypothesis that TFP reflects the only technological change. The dynamics of the total factor productivity is influenced by various factors, both local and global.

The literature on the influence of various factors on one-factor and multifactorial performance is quite extensive. We will note a few works that are closest to the subject of this study. The impact of R\&D on multi-factor productivity growth has been assessed in a study (Guellec, van Pottelsberghe de la Potterie, 2001). It is shown that in countries with a high intensity of $R \& D$ expenditures, the contribution of the growth of these expenditures to the growth of total factor productivity is higher than in countries with a low share of R\&D expenditures in GDP. The impact of public policy instruments on R\&D spending has been studied in (Guellec, Van Pottelsberghe De La Potterie, 2003; Balashova, 2015). The work (den Butter, EsSaghir, 2013) analyzes the impact of international trade and, mainly, trade of high-tech goods, on TFP dynamics, empirical analysis is carried out for a number of OECD countries. The impact of innovation, education, institutions, infrastructure has been studied in the works of experts from the World Bank (Kim, Loayza, $2017,2019)$. It is shown that the intensity of the influence of these factors is different for different groups of countries, and general patterns are highlighted.

Another aspect, namely the influence of uncertainty in commodity markets on macroeconomic indicators, has been studied by A. Serletis and his colleagues (Elder, Serletis, 2010; Azad, Serletis, 2020). Our study assumes that uncertainty in commodity markets affects the cyclical component of the growth rate of total factor productivity.

\section{Empirical research methodology}

The time series of TFP growth rates, like any time series, can be represented as a combination of trend $\Delta \ln \left(\mathrm{TFP}^{T R}\right)_{i t}$, cyclical $\Delta \ln \left(\mathrm{TFP}^{\mathrm{Cycle}}\right)_{i t}$ and random components $\varepsilon_{i t}$ :

$$
\Delta \ln (\mathrm{TFP})_{i t}=\Delta \ln \left(\mathrm{TFP}^{T R}\right)_{i t}+\Delta \ln \left(\mathrm{TFP}^{\mathrm{Cycle}}\right)_{i t}+v_{i t},
$$

where $i$ is the country index, $t$ is the time index.

Let us accept the hypothesis that the cyclical component is related to the state of the world economy and affects the rate of TFP change in any country in the context of globalisation. 


$$
\Delta \ln \left(\text { TFP }^{\text {Cycle }}\right)_{i t}=F_{i}(\text { Global conditions } t),
$$

Here $F i$ is a function specific to each country. In the simplest case, $\Delta \ln \left(\text { TFP }^{\text {Cycle }}\right)_{i t}$ is a linear function of an indicator characterizing the state of the world economy (the coefficients of this linear equation may be different for different countries).

To characterize global conditions in this study, we selected the volatility indicator of world oil prices, estimated using the GARCH-M $(1,1)$ model for the cyclical component of the Brand oil price. In order not to deviate from the main goal of the study, we will omit a more detailed description. We only add that the GARCH-M $(1,1)$ model is generally accepted for assessing volatility (see, for example, (Aye et al., 2014)).

The trend component of TFP reflects technological changes that grows over time, which, however, is not evenly distributed across countries. The ability of a country to generate new knowledge and technologies, the ability of a country's economy to apply advanced technologies, affects how the general technological trend will affect the TFP of each economy.

$R \& D$ expenditures are a key characteristic of the level of development of the national innovation system. Based on the studies mentioned above, we use the volume of foreign trade to characterize the effect of knowledge and technology spillover, as well as to account for the benefits from the international division of labour and participation in international economic relations.

Considering the above, as a model for the TFP growth rate $\Delta \ln (\text { TFP })_{i t}$, a model is proposed

$$
\Delta \ln (\mathrm{TFP})_{i t}=\alpha_{i}+\beta \Delta \ln (R D)_{i t}+\delta \Delta \ln (\text { Trade })_{i t}+\gamma \mathrm{Vol}+\varepsilon_{i t},
$$

where $\Delta \ln (R D)_{i t}$ is the growth rate of R\&D expenditures, $\Delta \ln (\text { Trade })_{i t}$ is the growth rate of foreign trade volumes, Vol is the oil price volatility; $\alpha, \beta, \gamma$ and $\delta$ are model parameters, and $\alpha$ reflects the influence of time-constant factors specific to each country.

We estimate the parameters of the model (4) using the method of least squares with fixed effects for panel data. Standard errors are corrected by White's method to account for heteroscedasticity.

The data for empirical analysis were retrieved from the TED (Total Economy Database, 2019), MSTI OECD, and World Bank Database. R\&D expenditures and foreign trade volumes have been converted into constant international dollars for correct cross-country and cross-temporal comparison.

\section{Empirical results and discussion}

The dynamics of total factor productivity is highly volatile. Figure 1 shows the TFP dynamics for EU countries, aggregated over $28 \mathrm{EU}$ member-countries as of 2019. The trend component changes quite smoothly, demonstrating growth from the beginning to the mid-90s, then a gradual decline and a transition to negative growth rates in the middle of the first decade of the XXI century. The cyclical component is fluctuating with large amplitude. A sharp drop in TFP growth rates in 2009 closely correlates with a sharp increase in oil price volatility (right axis in Figure 1). 




$\begin{array}{lllllllllllllll}90 & 92 & 94 & 96 & 98 & 00 & 02 & 04 & 06 & 08 & 10 & 12 & 14 & 16 & 18\end{array}$

- TFP Growth for EU28 -TREND

----. TFP Growth for EU28 -CYCLE

- - Volatility of Oil Proces

Figure 1. The growth rate of total factor productivity for EU countries and volatility of world oil prices (right axis)

Source: compiled by the authors.

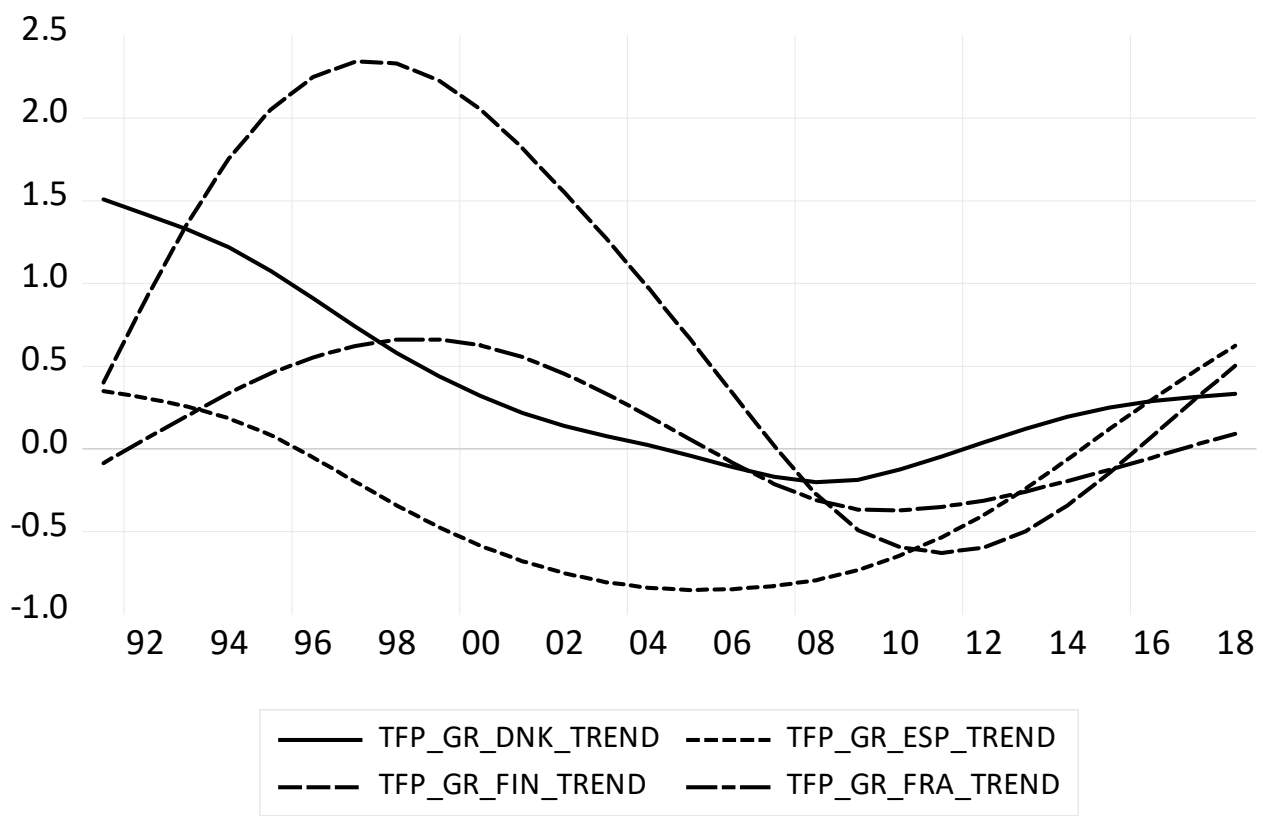

Figure 2. The growth rate of total factor productivity (trend component) for Denmark (DNK), Spain (ESP), Finland (FIN), France (FRA)

Source: compiled by the authors.

However, if the cyclical components' behaviour in most EU countries is the same, the trend components' behaviour is quite different. Figure 2 shows the dynamics of the trend component of the growth rate of total factor productivity for 
Finland, France, Denmark and Spain. It demonstrates that even among the developed "old" EU countries, there are no common patterns in productivity dynamics, except for the global impact of the 2008-2009 crisis.

Table 1 shows descriptive statistics for the variables of model (4): mean values, medians, and standard deviations for TFP growth rates, R\&D expenditures and international trade volumes, as well as characteristics of the volatility of world oil prices. Values are given for the entire set of EU countries, for the "old" EU-15 members and for the three Nordic countries.

Table 1

Descriptive statistics of model variables (4) for different groups of EU countries

\begin{tabular}{cccc}
\hline Переменная & \multicolumn{3}{c}{ EU countries / EU-15 / Nordic countries } \\
\hline & Mean & Median & St. deviation \\
\cline { 2 - 4 }$\Delta \ln ($ TFP) & $0.78 / 0.15 / 0.5$ & $0.7 / 0.26 / 0.62$ & $2.5 / 1.8 / 1.2$ \\
$\Delta \ln (R D)$ & $3.6 / 3.3 / 3.0$ & $3.3 / 3.8 / 3.2$ & $8.9 / 5.0 / 4.9$ \\
$\Delta \ln ($ Trade $)$ & $4.53 .7 / 3.3$ & $5.0 / 4.5 / 4.3$ & $8.5 / 7.1 / 7.7$ \\
Vol & 1.7 & 0.4 & 3.1 \\
\hline
\end{tabular}

Source: compiled by the authors.

As can be seen from Table 1, despite a sharp drop in TFP growth rates in 2009, the average value for all considered groups is positive. For the Nordic countries, the average growth rate is higher, and the standard deviation is lower than for the EU15. This suggests that, on average, these countries are more stable in increasing the total factor productivity than other "old" EU members. However, "new" EU members provide higher TFP growth for the EU as a group. At the same time, the growth rates of $\mathrm{R} \& \mathrm{D}$ expenditures, as well as the growth rates of foreign trade for the Nordic countries, are on average the same as for other groups of countries. So, we assume that specific factors provide higher TFP growth rates for Denmark, Sweden, and Finland, not only model's (4) factors.

The results of estimating the parameters of the model (4) are shown in Table 2. The estimation was carried out for 24 EU countries (due to the availability of data) from 1990 to 2018. In the right column of Table 2, we show results for the three Nordic countries (Denmark, Sweden, Finland) already mentioned to be global innovation leaders.

Table 2

Estimation of model parameters for the growth rate of total factor productivity

\begin{tabular}{|c|c|c|}
\hline Variable & Full sample (EU countries) & $\begin{array}{c}\text { Nordic countries } \\
\text { (Denmark Finland, Sweden) }\end{array}$ \\
\hline$\Delta \ln (R D)$ & $\begin{array}{l}0,03^{\star *} \\
(0,01)\end{array}$ & $\begin{array}{l}0,06^{\star *} \\
(0,03)\end{array}$ \\
\hline$\Delta \ln ($ Trade $)$ & $\begin{array}{c}0,11^{\star * \star} \\
(0,03)\end{array}$ & $\begin{array}{c}0,15^{\star * \star} \\
(0,03)\end{array}$ \\
\hline Vol & $\begin{array}{c}-0,27^{\star \star \star} \\
(0,05)\end{array}$ & $\begin{array}{c}-0,25^{\star \star \star} \\
(0,05)\end{array}$ \\
\hline$R^{2}$ & 0,49 & 0,75 \\
\hline$N$ & 558 & 63 \\
\hline
\end{tabular}

Note. ${ }^{*}$ OLS estimates of parameters and standard errors (in parenthesis) are given. ${ }^{*}$ Significance at the $5 \%$ level. ${ }^{\star \star \star}$ Significance at the $1 \%$ level.

Source: compiled by the authors. 
The assessment results show that the model is much better fitted for the Nordic countries - leaders in innovative development than for the EU as a whole. A $75 \%$ change in the regressors included in equation (4) explains the change in the growth rate of total factor productivity, while for the EU countries as a group, the model expaines less than $50 \%$ of the variability in TFP growth rates. Moreover, the Nordic countries' TFP growth rates are more sensitive to changes in the growth rate of R\&D expenditures than in the EU as a whole.

What factors can be identified that determined the Nordic countries' leadership in innovative development and made it possible to obtain higher rates of total factor productivity?

\section{Supporting innovations in Nordic countries}

A distinctive feature of the Nordic countries is their developed national innovation system (NIS), which is built on the principle of a "triple helix" (Reshetnikova, 2020). All the elements of such a spiral - the state, companies, universities closely interact. The high level of cooperation between the various elements of the spiral provides a higher innovative return. In addition, another distinctive feature of all Nordic countries (including Norway and Iceland) is the focus on the use of regional potential. Thus, governments develop strategies, and regions carry out appropriate measures, which increases the speed of making innovative decisions and ensures a certain even distribution of innovative results.

The main government body that determines innovation policy in Finland is the Research and Innovation Council. The Ministry of Education and Culture oversees the activities of the Academy of Sciences and universities. The Ministry of Education, Science and Culture and the Ministry of Trade and Industry account for $80 \%$ of all government R\&D spending in Finland. The government agency Tekes plays an important role in NIS Finland, which supports research, technology development and innovation. The agency makes independent decisions regarding the financing of scientific projects. Another state-owned company, Sitra, is supporting startups and venture funding. An important link in NIS is the Finnish Technical Research Center (VTT), which focuses on the following social problems and growth opportunities for Finland: climate, resource sufficiency, quality of life, safety, industrial modernization. Even though in the structure of R\&D expenditures a large share belongs to the entrepreneurial sector (on average, about $60 \%$ of all R\&D expenditures in 2010-2018), the public sector plays an important role in coordinating innovation policy.

Sweden also has an extensive system of state support for innovation. The Government is in charge of developing the innovation strategy, with the key ministries being the Ministry of Education and Research and the Ministry of Entrepreneurship and Innovation. These ministries manage the Swedish Research Council, the Venture Capital and Long-Term Loan Fund, the Swedish Management of Innovation Systems, the Small and Medium Business Support Fund, the Strategic Research Fund and other funds and organizations.

TNCs (Volvo, Ericson, Scania, Skanska and others), which are actively developing innovative products, have made a great contribution to innovative Sweden. 
Thus, we can say that in the Nordic countries, there are well-developed institutions to support innovation. For this indicator, countries are leaders in conducting a comprehensive assessment of the level of innovative development.

The Global Innovation Index (GII), calculated annually by the INSEAD International Business School in cooperation with Cornell University and the World Intellectual Property Organization, is a widely recognized tool for assessing the level of innovation. For a number of years, Sweden has been recognized as one of the global leaders in innovative development; in 2020, this country took $2^{\text {nd }}$ place in the world, behind only Switzerland in the ranking. Sweden has a strong record in both Innovation Input and Innovation Output. The list of top 10 countries in innovative development includes Finland ( $8^{\text {th }}$ position) and Denmark ( $9^{\text {th }}$ position).

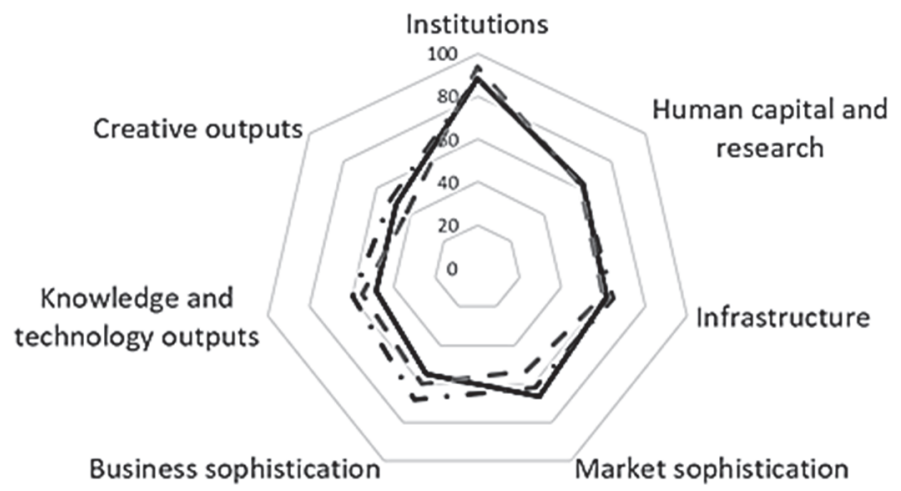

Denmark - - Finland - Sweden

Figure 3. Assessment of the development level of the Nordic countries according to 7 Gll indicators (2020), score

Source: compiled by the authors based on data from the Global Innovation Index.

Figure 3 clearly shows a comprehensive assessment of the level of innovative development of the Nordic countries, taking into account the structure of the GII, which includes 5 indicators that assess countries' resource capacity for innovation, and 2 indicators characterising the effectiveness of innovation.

All the Nordic countries, especially Denmark, Sweden, and Finland, have highly developed institutions that promote innovation. These countries have high scores on Government effectiveness, Political environment, Regulatory quality, Rule of law.

The indicators of the group Human capital and research have high marks in the leading countries. High spending on education and $R \& D$, the number of researchers per capita, the length of secondary education and enrollment in higher education are the strengths of the resource component of innovation in all three countries.

Infrastructure development is also assessed quite high in all three countries. Here, it is necessary to highlight such an indicator as E-participation (public participation in political and public life using information and communication technologies), which is estimated at 100 points in Denmark and Finland, and quite high in Sweden. In general, all indicators related to the use of ICT as a resource have high scores (except for the indicator ICT access). 
The performance of activities in the field of knowledge and technology is highly appreciated in leading countries due to patent activity, a large share of exports of ICT services and payments for intellectual property received in the total volume of foreign trade.

Nevertheless, despite the overall high level of innovation activity, the growth rate of labor productivity (Growth rate of PPP $\$ G D P /$ worker) in these countries is low (Denmark has the highest position in this indicator among the Nordic countries, ranking $65^{\text {th }}$ in the ranking GII). The paper (Balashova, 2016) shows that the effect of increased innovation activity is most noticeable for countries with relatively low levels of productivity and practically insignificant for countries with a high level of GDP per worker, which include the three Nordic countries under consideration. And despite the undeniable link between innovation and economic growth, this link is not linear and requires continuous improvement in transmission mechanisms.

\section{Conclusion}

This article examines the relationship between productivity and innovation activity in the Nordic countries. Sweden, Finland and Denmark have been in the top 10 most innovative countries according to the GII for eight years. Labour productivity growth rates are not high in these countries. However, the growth rates of the total factor productivity (labour and capital) for global innovation leaders to a much greater extent depend on such key indicator of the development of innovative activity as R\&D spending than for the EU countries as a group. Large expenses by themselves do not provide innovative leadership and the growth of total factor productivity, but in combination with the high quality of political and social institutions, the all-round development of the national innovation system according to the triple helix principle, developed infrastructure and widespread use of ICT, R\&D spending makes a significant contribution to productivity increase. Historically, the Nordic countries specialized in the extraction and processing of natural resources (for example, in Sweden it is iron, copper, lead, zinc, etc.; in Finland - timber, copper, zinc, silver), but now these countries are successfully developing technologies and innovation, which, when exporting, provides not only a higher value added but also the preservation of natural resources.

The Nordic countries' experience can be useful for finding development mechanisms for those regions of Russia that do not have their own resource base, powerful industrial potential or unique natural and climatic conditions. The Nordic countries are countries with small economies, low populations and rather difficult climatic conditions. Simultaneously, well-thought-out innovative national development strategies and strong support from the European centre allowed these countries to become European and world innovative leaders. And they provided a higher return on research and innovation compared to other European countries.

\section{References}

Aye, G.C., et al. (2014). Oil price uncertainty and manufacturing production. Energy Economics, 43, 41-47. doi: 10.1016/j.eneco.2014.02.004.

Azad, N.F., \& Serletis, A. (2020). Oil price shocks in major emerging economies. SSRN Electronic Journal, (403). doi: 10.2139/ssrn.3577378. 
Balashova, S. (2015). The impact of public R\&D policy on business-funded R\&D (case of OECD countries). Applied Econometrics, 2(38), 244-250. (In Russ.)

Balashova, S. (2016). The impact of innovation activity on socio-economic performance: Empirical evidence for European countries. SGEM International Multidisciplinary Scientific Conference on Social Sciences and Arts (pp. 777-784). Sofia. doi: 10.5593/sgemsocial2016B25.

Cubeddu, M.L.M., et al. (2014). Emerging markets in transition: Growth prospects and challenges. International Monetary Fund.

Den Butter, F., \& Es-Saghir, A. (2013). Productivity effects of trade and product innovations: An empirical analysis for 13 OECD countries. Applied Economics, 45, 4412-4418. doi: $10.1080 / 00036846.2013 .786167$.

Elder, J., \& Serletis, A. (2010). Oil price uncertainty. Journal of Money, Credit, and Banking, 42(6), 1137-1159. Retrieved November 11, 2020, from https://papers.ssrn.com/sol3/ papers.cfm?abstract id $=908675$

Global Innovation Index. (n.d.). About the Global Innovation Index. Retrieved November 11, 2020, from https://www.globalinnovationindex.org/about-gii\#reports

Guellec, D., \& Van Pottelsberghe de la Potterie, B. (2001). R\&D and productivity growth: Panel data analysis of 16 OECD countries. doi: 10.1787/652870318341.

Guellec, D., \& Van Pottelsberghe De La Potterie, B. (2003). The impact of public R\&D expenditure on business R\&D. Economics of Innovation and New Technology, 225-243.

Jorgenson, D.W., Vu, K.M. (2016). The ICT revolution, world economic growth, and policy issues. Telecommunications Policy, 40(5), 383-397. doi: 10.1016/J.TELPOL.2016.01.002.

Kim, Y.E., \& Loayza, N.V (2017). Productivity and its determinants: Innovation, education, efficiency, infrastructure, and institutions. Retrieved May 27, 2018, from http://pubdocs.worldbank.org/ en/378031511165998244/Productivity-and-its-determinants-25-October-2017.pdf

Kim, Y.E., \& Loayza, N.V. (2019). Productivity growth: Patterns and determinants across the world. Economia, 42(84), 36-93. doi: 10.18800/economia.201902.003.

Maslennikov, O.V. (2015). Klassifikaciya metodov rascheta sovokupnoj faktornoj proizvoditel'nosti [Classification of methods of calculation of cumulative factorial productivity]. Proceedings of Voronezh State University, (4), 172-175. (In Russ.)

Matyushok, V.M. (2011). The thorny path to innovatove economy. Bulletin of the Peoples' Friendship University of Russia, (S5), 141-157. (In Russ.)

Matyushok, V.M., \& Kravtsov, A. A. (2011). European way to innovative economy. Bulletin of the Peoples' Friendship University of Russia, (4), 44-54. (In Russ.)

OECD (2001). Measuring productivity - OECD manual. doi: 10.1787/9789264194519-en.

Reshetnikova, M. (2020). Venture capital market in China: A new approach to innovation management. http://doi.org/10.5281/zenodo.3984247

Sinha, R. (2017). Long-term growth scenarios for Bangladesh. WPS 7952. Retrieved November 11, 2020, from http://documents.worldbank.org/curated/en/131961485274754618/Long-term-growth

Solow, R. (1956). A contribution to the theory of economic growth. Quarterly Journal of Economics, 70, 65-94.

Total Economy Database. (2019). Key Findings. Retrieved March 1, 2020, from https://www.conference-board.org/data/economydatabase/

\section{Сведения об авторах / Bio notes}

Балашова Светлана Алексеевна, кандидат физико-математических наук, заведующая кафедрой экономико-математического моделирования экономического факультета Российского университета дружбы народов. E-mail: balashova-sa@rudn.ru.

Абрамова Анастасия Андреевна, студентка 4-го курса кафедры экономико-математического моделирования экономического факультета Российского университета дружбы народов. E-mail: 1032173040@rudn.ru.
Svetlana A. Balashova, $\mathrm{PhD}$ in Physics and Mathematics, Head of the Department of Economic and Mathematical Modeling of the Faculty of Economics of the Peoples' Friendship University of Russia (RUDN University). E-mail: balashova-sa@rudn.ru.

Anastasia A. Abramova, bachelor of the Department of Economic and Mathematical Modeling of the Faculty of Economics of the Peoples' Friendship University of Russia (RUDN University). E-mail: 1032173040@rudn.ru. 